\title{
Maurice Merleau-Ponty's Criticism on Bergson's Theory of Time Seen Through The Work of Gilles Deleuze
}

\author{
Judith Wambacq \\ Ghent University, Belgium
}

\begin{abstract}
In this article I examine the relation between the philosophies of Maurice Merleau-Ponty and Gilles Deleuze by looking at the way they refer to the time theory of Henri Bergson. It appears that, although Merleau-Ponty develops some fundamental Bergsonian insights on the nature of time, he presents himself as a critical reader of the latter. I will show that although Merleau-Ponty's interpretation of Bergson differs fundamentally from Deleuze's interpretation, Merleau-Ponty's "corrections" of Bergson's theory fit Deleuze's reading of Bergson very well. This indicates a similarity with respect to what is at stake in the philosophies of Merleau-Ponty and Deleuze. The critical reference that Deleuze makes to Merleau-Ponty's conception of cinema and thus of movement is hence not justified, but is the result of a selective and prototypical reading of the early Merleau-Ponty.
\end{abstract}

Keywords: Time, Movement, Cinema, Memory, Virtual.

\section{Introduction}

The general impression among Deleuze's readers is that Deleuze had no patience for phenomenology. Many of his references to phenomenology, and especially to the general orientation of phenomenological inquiry, are disparaging. There are some scholars, however, such as Alain Beaulieu, who believe that phenomenology is Deleuze's invisible enemy, the adversary he needs in order to develop his own thought. And he invokes a Nietzschean idea to characterize Deleuze's antagonism to phenomenology: contrary to a war, a combat does not imply the suppression of one's opponent, but always presupposes some respect for-and even love of - the enemy, because one shares in the 
strength and excellence of one's enemy. Beaulieu thus calls phenomenology Deleuze's "beloved enemy" or "friend-enemy". ${ }^{1}$

While I do not deny Deleuze's antagonistic relation to phenomenology, I would like to examine what "love" or "friendship" there is within this couple and, more particularly between Deleuze and Merleau-Ponty. There what is at stake in both philosophies, and the ways in which they express their philosophies. One way of exploring these similarities is by examining how both authors read and use Henri Bergson, a philosopher they knew very well and referred to often in their own work. In this article, I will focus on Bergson's theory of time. This famous theory could not be absent in the temporality chapter of Merleau-Ponty's Phenomenology of Perception or from Deleuze's books on cinema, which are an examination of how cinema presents time. I believe that an examination of how both thinkers rework Bergson's theory of time,which ideas they attack, and how they adapt them, can reveal something about the similarities and differences in their positions.

\section{Deleuze's discussion of Bergson's theory of time}

It may seem at first sight that the whole project of using Bergson to look for resonances between Merleau-Ponty's and Deleuze's conceptions of time is threatened by the following statement from Deleuze:

It was necessary, at any cost, to overcome this duality of image and movement, of consciousness and thing. Two very different authors were to undertake this task at about the same time: Bergson and Husserl. Each had his own war cry: all consciousness is consciousness of something (Husserl), or more strongly, all consciousness is something (Bergson). ${ }^{2}$

According to Deleuze, Bergson's attempt to overcome the "duality" of image (or consciousness) and movement (or body) is fundamentally cinematographic, whereas Husserl's phenomenological attempt has to be considered pre-cinematographic. Bergson's strategy, in other words, is radically different from phenomenology's. Why is that?

1 "Unlike the warrior, the combatant is not simply satisfied with suppressing his opponent. He increases his own power through the productive appropriation of the power of his vanquished opponent. The stronger the opponent is, the more likely it is that the combatant can increase his own power." (A. Beaulieu, Gilles Deleuze et la phénoménologie, Mons: Les Editions Sils Maria, 2004, p. 261, transl. mine) See also: "Consequently, phenomenology is Deleuze's friend because it is an extrinsic point capable of giving consistency to his philosophical project; but it is also an implicit enemy, without which Deleuze's thought would remain abstract." (ibid., p. 11) The notions of "beloved enemy" and "friend-enemy" are further discussed on p. 257 and p. 260, respectively

${ }^{2}$ G. Deleuze, Cinema 1. The Movement-Image, English trans. by H. Tomlinson and B. Habberjam), London/New York: The Athlone Press, 1986, [1983], p. 56 [pp. 83-84]. Henceforward abbreviated as $\mathrm{C} 1$. 
The image, which Bergson defines as something that acts and reacts on other images in every one of its elementary parts, ${ }^{3}$ is central to Bergson's argument. An image is thus defined by the movements it undergoes and exerts; an image is nothing more than movement. Since for Bergson both things and consciousness are images, the dualism between them is dissolved. And since moving images are the instruments of cinema, Deleuze argues that this overcoming of dualism is cinematographic. ${ }^{4}$

Bergson's overcoming of dualism issues in a theory of movement. And it is here, exactly, that Deleuze situates the core difference between Bergson's antidualism and phenomenology's. Bergson holds that movement has nothing to do with a thing's transition from one position in space to another; such a view, he argues, denies movement any creative character. After all, according to that view, the moved thing only differs from the unmoved thing in that it occupies a different spatio-temporal position. Time is thus reduced to a homogeneous line-it is the same at all moments and evolves linearly-on which things can occupy different places. Time is an independent variable. It is spatialized because it is understood as the juxtaposition of arbitrary (because exchangeable), immobile and external moments or, as Deleuze calls it, of "any-instantswhatever." 5 Bergson, on the contrary, believes that moments do differ, that is, that they can evolve towards a qualitatively different state. Every figure has its particular or singular movement or inner becoming. Moreover, time is what makes things change in a qualitative way; time is change, movement,

${ }^{3}$ H. Bergson, Matter and Memory, English trans. by N.M. Paul, and W.S. Palmer, New York: Dover Publications, 2004 [1939], p. 28 [p. 33].

${ }^{4}$ Bergson himself would never have used this characterization since he condemns cinema for reconstituting movement in an improper way, i.e., by making immobile sections or images succeed one another (H. Bergson, Creative Evolution, English trans. by A. Mitchell, New York: Henry Holt and Company, 1924 [1941], p. 305-306 [p. 304-306]). Deleuze's innovation consists in combining Bergson's analysis of movement with a new, non-Bergsonian understanding of cinema. According to Deleuze, cinema presents us with real movement exactly because it uses sections or any-moments-whatever. What Bergson notices about scientific any-momentswhatever, but which he refused to transpose to cinema, is that these any-moments-whatever indicate that the movement of which they are the terms is not existentially or essentially predetermined; they determine movement immanently and materially. Contrary to Bergson, Deleuze thinks that cinematographic moments have a qualitative nature (C1, p. 8 [pp. 18-19]). These qualities are the result of movements of translation between the moments, such that the whole changes. It is thus not so much the moments themselves but the relations between them that determine the qualities (i.e., the so-called externality of the relation to its terms). In her article "Deleuze and the Limits of Mathematical Time", Dorothea Olkowski identifies two more divergences between Deleuze's and Bergson's theory of time: Deleuze gives short shrift to Bergson's idea that "there is no duration without consciousness and no before and after without memory," and to Bergson's notion that the body and its affectivity are situated outside the plane of immanence (D. Olkowski, "Deleuze and the Limits of Mathematical Time," in Deleuze Studies, vol. 2, n ${ }^{\circ}$, p. 14).

${ }^{5}$ C1, p. 4 [p. 13]. 
creation. In Bergson's terms: there exists a duration immanent to the whole of the universe and this duration has to be understood as "invention, the creation of new forms, the continual elaboration of the absolutely new." "The impersonal, abstract and simple movements examined by modern sciences are just deductions of that.

Apart from the spatialized view of time initiated by the modern sciences of nature 7 ,Bergson mentions another "wrong" conception of movement, namely, the one offered by the ancient Greeks. The Greeks, like the moderns, do not ascribe a constitutive value to time; instead, they conceive time, again like the moderns, as being neutral. Ultimately, what matters to the Greeks are infinite and immobile Essences or Ideas, such that movement is reduced to the transition between these Essences. Movement is the "regulated transition from one form to another, that is, an order of poses or privileged instants." Time is only the frame necessary to think this transition. But it is irrelevant in itself-it has no direct influence on the essences.

Deleuze situates Merleau-Ponty in the same tradition as the Greeks. Merleau-Ponty also understands movement as the passage of immobile, privileged moments, except that, for him, these moments are no longer essential but existential. He does not invoke intelligible forms but perceivable Gestalts that organize our field of perception in accordance with our being-towards-theworld, such that this being-towards-the-world constitutes the fixed anchorpoint of perception'. For Deleuze, Merleau-Ponty's neutral conception of time does not accord time any effective power; Merleau-Ponty's (and phenomenology's) anti-dualism cannot be put on a par with Bergson's.

Is Deleuze's presentation of Merleau-Ponty's conception of time correct? Is Merleau-Ponty's conception as different from Deleuze's as we might think it is, given the difference between Merleau-Ponty and Bergson mentioned above and the fact that Deleuze explicitly aligns his theory of time with Bergson's? Since we are especially interested in examining the relationship between

${ }^{6} \mathrm{H}$. Bergson, Creative Evolution, English trans. by A. Mitchell, New York: Henry Holt and Company, 1924 [1941], p. 11 [p. 11]

${ }^{7}$ H. Bergson, Creative Evolution, English trans. by A. Mitchell, New York: Henry Holt and Company, 1924 [1941], p. 314-318 [p. 313-318]) See also: C1, pp. 3-4 [pp. 12-13].

${ }^{8}$ C1, p. 4 [p. 13].

${ }^{9}$ C1, p. 57 [p. 84]. According to Deleuze, Merleau-Ponty rejects cinema precisely because it detaches perception from its lived horizon, such that it presents a world devoid of reality, completely transparent and isolated. In the Phenomenology of Perception, Merleau-Ponty does indeed write that the screen has no horizon and that the horizon makes things meaningful and gives them their identity (PP, p. 82). But there are other texts where Merleau-Ponty is far less negative towards cinema. Both in L'ontologie cartésienne et l'ontologie d'aujourd'hui and in the (still unpublished) course notes Le monde sensible et le monde de l'expression, Merleau-Ponty suggests a convergence between cinema’s ontology and his own (later) endo-ontology. See M. Carbone, "Le_philosophe et le cinéaste. Merleau-Ponty et la pensée du cinema," in Chiasmi International 12 (2010), Merleau-Ponty. Philosophie et movement des images, pp. 47-70. 
Merleau-Ponty and Deleuze, we shall not examine whether or not MerleauPonty's and Deleuze's views about Bergson's theory of time square with Bergson's texts. In other words, we shall not examine whether Merleau-Ponty's and Deleuze's interpretations of Bergson do his work justice. We shall instead limit ourselves to examining how Merleau-Ponty refers to Bergson in Phenomenology of Perception and The Visible and the Invisible, the two key texts for Merleau-Ponty's treatment and understanding of time. How does he attack Bergson's conception of time and what does he propose as an alternative? As we compare Merleau-Ponty's reading of Bergson with Deleuze's, it will become clear that what Merleau-Ponty sets forward as an alternative to Bergson corresponds in fact to what Deleuze finds in Bergson; thus Deleuze's distance to Merleau-Ponty is not as great as it might seem at first sight.

\section{Bergson in the Phenomenology of Perception}

Merleau-Ponty brings up Bergson in the Phenomenology of Perception in the context of a discussion about the nature of the relation between language and thinking. Do we need a representation of a word in order to be able to speak it? Do we rely on acquired linguistic images when we speak? As this is a question about linguistic memory, and as memory is one of the ways we experience time, this discussion between Merleau-Ponty and Bergson is very useful for our inquiry.

Merleau-Ponty argues that it is a mistake to presuppose that a separate level of determinate representations of past experiences or facts serves as the pool wherein we search for our memories. We do not retrieve a memory by looking for similarities between the current linguistic context and our representations of past ones. The study of several kinds of amnesia had revealed that people are quite capable of using stored knowledge without being able to make representations of that knowledge. ${ }^{10}$ Patients who suffer from aphasia, for example, scream, "Ah, a mosquito!," when they are bitten in the arm. And yet, they are unable to retrieve the word from their memory when asked to name the flying insect that bit them.

Secondly, if remembering a word were synonymous with looking for similarities between a particular linguistic situation and previous ones, the success of the operation would boil down to sheer luck. A present situation can look like a previous one in a thousand ways; every situation resembles an old one in one way or another. In short, a theory anchored to the notion of a database of representations of past experiences does not explain how similarities are being determined, and thus simply replaces one mystery with another.

${ }^{10}$ M. Merleau-Ponty, Phenomenology of Perception, English trans. by C. Smith, London/ New York: Routledge and Kegan Paul, 1962 [1945], pp. 174-175 [pp. 203-204]. Henceforward abbreviated as PP. 
Merleau-Ponty does not think that the act of remembering entails searching into remote areas of our consciousness; our past, on the contrary, is always already with us. Merleau-Ponty here draws upon Husserl's theory of retentions and protentions: the past and the future do not consist of a succession of external 'now' instances, that have either passed or are to be expected, but they are enveloped in the living present ${ }^{11}$. When we perceive a situation, we always experience it against, or, more correctly, through the horizon of our past experiences. Somebody's perception of a dog, for example, might always be shaped by her memory of having been bitten by one once. Moreover, the memory of this past event is not restricted to the characters present at the biting incident, but spreads out to her entire past.Her seeing of the dog now before her is thus shaped not only by her memory of the dangerous dog of her past, but also by hermemory of that dog's owner, of herrelationship with the owner, of perhaps the romantic setting theywere in, etc. Her entire past, in other words, is concentrated in her present perception. ${ }^{12}$

Moreover, Merleau-Ponty adds that remembering is not a representational matter. When we need to recall a word, for example, it is not so much the meaning of what we would like to say that guides us towards the word we are looking for, but the tone of the current context and of the word we are searching for. It is the "emotional essence" we have retained of the word, the way it is pronounced and the style of its sound that will shape the word in our

${ }^{11}$ In The Time of Half-Sleep: Merleau-Ponty between Husserl and Proust, Mauro Carbone convincingly demonstrates how Merleau-Ponty's conception of time undergoes a fundamental change in The Visible and the Invisible. Whereas Phenomenology of Perception was still marked by Husserlianism -in the sense that it eventually fell back on the duality of a transcendent consciousness versus its object-The Visible and the Invisible renounces this sort of transcendence and replaces it with the transcendence of flesh, its thickness, its being at a distance, its being visible-invisible. The sense of time, instead of being constituted through "a series of intentional acts, which present the link between past and present as adhesion of the consciousness of the past to the consciousness of the present" (p. 9), is now generated out of the differentiations that take place in the spatializing-temporalizing vortex itself (the flesh), out of its being envelopingenveloped. Thus, the retentions no longer refer to the intentional act of consciousness but to the operative intentionality within being itself. In addition, Merleau-Ponty not only supplements Husserl's continuity thesis with the idea of the constitutive value of discontinuity(for example, forgetting is understood as a condition for an access to the past) he also renounces the linearity and seriality present in Husserl's conception of time. (M. Carbone, The Thinking of the Sensible. Merelau-Ponty's A-Philosophy, Evanston/Illinois, Northwestern University Press, 2004, pp. 1-13) According to Fabrice Colonna, the anti-Husserliantheory of time of The Visible and the Invisible is fundamentally influenced by Merleau-Ponty's reading of Bergson. (F. Colonna, "Merleau-Ponty et la simultanéité," in Chiasmi International 4 (2002), Merleau-Ponty. Figures et fonds de la chair, p. 216)

12 "The objective landmarks in relation to which I assign a place to my recollection in the mediatory identification, and the intellectual synthesis generally, have themselves a temporal significance only because gradually, step by step, the synthesis of apprehension links me to my whole actual past" (PP, p. 418 [p. 478], italics mine). 
mouths. ${ }^{13}$ Memory, consequently, is not a function of representational thinking but of a bodily being-towards-the-world in which the past is not relegated to a remote area but is always interacting, in its entirety, with what we do and see here and now.

Where is Bergson in these observations? Merleau-Ponty himself credits Husserl, but the similarities with Bergson are unmistakably clear both in the idea of the simultaneity of past and present and in the idea of the present as a contraction of the past in its entirety. Merleau-Ponty acknowledges Bergson's influence when he discusses how memory-images are elicited by the current situation and its specific sensory-motor interest. But-and this is interesting for us - he accuses Bergson of not being radical enough. The current situation is only the empirical trigger for the memories, while the transcendental origin of these memories is situated in a transcendent order: that of the pure past. In Bergson's account, the practical, current situation is not necessary to actualize the pure past:

[...] the verbal image is only one of the modalities of my phonetic gesticulation, presented with many others in the all-embracing consciousness of my body. This is obviously what Bergson means when he talks about a "motor framework" of recollection, but if pure representations of the past take their place in this framework, it is not clear why they should need it to become actual once more. ${ }^{14}$

As Fabrice Colonna puts it, Merleau-Ponty thinks Bergson does not recognize the transcendent moment in the present itself. Bergson doubles the present with a virtual layer, the pure past, such that both layers are extrinsic to one another. ${ }^{15}$ It is not clear, in other words, how the virtual past and the actual present are linked in Bergson. Merleau-Ponty, for his part, anchors the pure past in the present by relying on the notion of depth developed by Erwin Straus. Straus says that when we perceive something as being far away,

${ }^{13}$ PP, p. 180 [p. 210].

${ }^{14}$ PP, p. 181 [p. 210-211].

15 "Because he adheres to the presupposition of presence, Bergson fails to recognize the present's essential distance, and this leads him to redouble the present with the virtual shadow of the past, instead of thematizing its transcendence. [...] While Bergson sees the present's constitutive split as a redoubling, Merleau-Ponty sees it as a dehiscence. Merleau-Ponty rejects the notion of the present that is weakened into the past (empiricism), and the notion that the present is different in nature from the past that redoubles it (Bergson). He posits a present that is already transcendence, distance, a present that can harbor the past, the imaginary, the dream, the phantasm. The past is already the past of the present it had been, but not because there is a "consecutive image" of the present-that is to say, once again, a limit between present and past - but for the more fundamental reason that the present is not a positive presence-the present is always already other." (F. Colonna, "Merleau-Ponty et la simultanéité," in Chiasmi International 4 (2002), Merleau-Ponty. Figures et fonds de la chair, p. 218, transl. mine). 
we do not rely only on a spatial intuition-how many steps removed from it are we?- - but also on a temporal one: the thing is perceived as being far away because we have to make an effort to reach it in the future, or because we have left it behind in the past. As a result, the present perception of a remote object always exceeds the dimension of the present and spills over into the past and the future. It is a spatial perception that is always already temporal or vice versa. By situating the origin of memories in the pure past, thus effectively refusing to give time a spatial inscription, Bergson reduces the past to a powerless, immaterial dimension. ${ }^{16}$ According to Colonna, that explains why Merleau-Ponty, despite his sympathy for Bergson's attempt to find a notion that could account for non-presence in the present or, in other words, for the presence of the past in the present, does not take over Bergson's notion of the virtual, but instead replaces it with "simultaneity" or "flesh."

Does Merleau-Ponty's criticism on Bergson hold? If we take Deleuze as our guide to reread Bergson's Matter and Memory, then we cannot but conclude that it does not. Let us divide Merleau-Ponty's criticism into two parts, analogous to the twofold structure of his alternative account of linguistic memory, and approach their refutation one at a time.

To begin with, Deleuze's reading of Bergson insists that Bergson's pure past cannot be regarded as transcendent with respect to the actual present. The well-known figure Bergson offers in chapter three of Matter and Memory ${ }^{17}$ - an inverted cone that specifies the present as a concentration of the virtual past—clearly suggests a continuity between pure memory (pure or virtual past), memory-image and actual perception. ${ }^{18} \mathrm{~A}$ memory that has been

${ }^{16}$ M. Merleau-Ponty, Notes de cours 1959-1961, Paris: Gallimard, 1996, p. 199.

17 "Perception is never a mere contact of the mind with the object present; it is impregnated with memory-images which complete it as they interpret it. The memory-image, in its turn, partakes of the "pure memory," which it begins to materialize, and of the perception in which it tends to embody itself: regarded from the latter point of view, it might be defined as a nascent perception. Lastly, pure memory, though independent in theory, manifests itself as a rule only in the coloured and living image which reveals it." (H. Bergson, Matter and Memory, English trans. by N.M. Paul and W.S. Palmer, New York: Dover Publications, 2004 [1939], p. 170 [p. 147]) See also G. Deleuze, Cinema 2. The Time-Image, English trans. by H. Tomlinson \& R. Galeta, London: The Athlone Press, 1989 [1985], p. 279 footnote 4 [p. 65]. Henceforward abbreviated as $\mathrm{C} 2$.

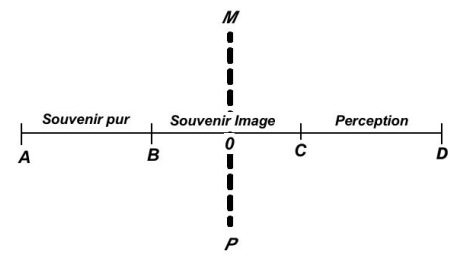

${ }^{18}$ C2, pp. 284-285 [p. 108]. Ronald Bogue explains Bergson's scheme as follows: "Bergson visualizes the virtual past as a cone, with its point representing the past's coincidence with the present, and its widening volume representing the ever-growing expanse of coexisting past 
recollected and has become an actual perception is the result of the focusing and contracting of the cloudy pure past or pure memory. ${ }^{19}$ Pure memory or pure past is thus not separated from the memory-images that are actualized into perceptions or representations. And the pure past, because it needs these actualizations to have any relevance, is not of a higher order than perceptions and memory-images. That is not to say, however, that perceptions, memoryimages and the pure past are the same thing. Their practical mingling notwithstanding, for Bergson, they are different in nature. Deleuze translates this immanent difference by calling the actual (perception) as well as the virtual (pure past) real. Both have ontological power, both create being-but not in the same way. The virtual is the driving force behind any kind of movement; indeed, the virtual is the power of creation: it is the endless play of differences itself. The actual, conversely, delineates and arrests the virtual into determinate forms. We will come back to this when responding to the second criticism.

Merleau-Ponty's second criticism is that Bergson's account of the past is essentially modeled on the image of present representations of the past. In so doing, "he makes time out of a preserved present, and evolution out of what

events. In that our past is preserved within itself and surges forward into the present, we can say that each present moment is a contraction of the past, a concentration of the entire cone in the point of its apex. Conversely, the endless expanse of the past may be regarded as a dilation of the present, the cone's spreading volume issuing forth from the apex of each present moment." (R. Bogue, Deleuze on Cinema, New York/London: Routledge, 2003, p. 136)

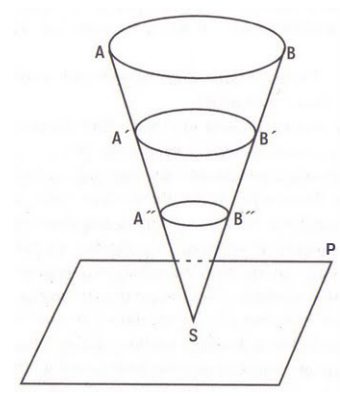

${ }^{19}$ In the Stanford Encyclopedia of Philosophy, the movement of actualization of a perception or representation out of pure memory is compared to the movement of a telescope: at first you see nothing or, which is the same, a nebula (pure memory precedes images; it is unconscious); then you rotate the rings that control the lenses in the telescope, at which point singular images of stars come into focus. This is the stage of fragmentation, the movement from unity to multiplicity and from multiplicity to juxtaposition. A second stage is needed: contraction. The images of the constellation must be narrowed, brought down the tube so that they fit into my eye. That is the movement from singular images to generalities, the very movement upon which actions can be based (http://plato.stanford.edu/entries/bergson/). See also G. Deleuze, Bergsonism, trans. H. Tomlinson \& B. Habberjam, New York, Zone Books, 1988 [1966], pp. 86-89 [pp. 88-91]) Henceforward abbreviated as B.. 
is evolved." ${ }^{20}$ To put the problem in Deleuzean terms: Merleau-Ponty thinks Bergson conceives of the condition in terms of the conditioned; he thinks the virtual by analogy with the actual. Deleuze approves of rejecting any philosophy that confuses the actual and the virtual, but he does not believe Bergson is guilty of this philosophical crime. Indeed, if Deleuze is so interested in Bergson, it is precisely because, according to him, Bergson offers a way out of tracing the condition from that which is conditioned. How is that?

Traditionally, the condition is thought after what is already there. We begin with what is, the real, and then proceed retrospectively to deduce what should have been the possibilities. The possible is then identified as the condition out of which the real develops itself. As such, the possible and the real are not fundamentally different: the real and the possible are the same, except for a surplus of existence on the side of the real. The real is a realized possibility. This conception of the condition makes it impossible to account for the appearance of something radically new, for one can only think in terms of what already is - one cannot capture the singularity of the real. ${ }^{21}$ Ultimately, this is not only a static, but also conservative image of the world, one where time is of no real influence. It reduces time to being the theoretical framework where the ideally possible develops into actual existence. Time is, as such, extrinsic to the event of realization: it has no proper ontological reality. ${ }^{22}$

Bergson, however, not only believes that something new can arise, he also believes that this happens all the time. The new, for him, is not prefigured, in one way or another, by the old. This implies that the creation, the emergence of something new, cannot be seen as the evolution in time of something already present into something different. It has to be seen, instead, as the evolution of time itself. Time, in other words, is not the container wherein events take place: it is itself the taking place of events. It is the production of qualitative differences, and not of quantitative variation. Within this conception of time as the production of qualitative differences, the emergent thing must be thought as a stagnation or a pause in the process of production. It must be thought as a (temporary) result of the process of differentiation, as something differentiated. Time is thus the condition out of which the created thing can evolve. As time is not made out of actual things, but is instead the becoming

${ }^{20}$ PP, p. 415 footnote 1 [pp. 474-475]

${ }^{21}$ B, p. 96-99 [p. 99-101])

22 “(...) time has no proper ontological reality whatsoever, since it would only be the framework wherein events happen, of which time has no grip on its possibilities, and if time does not do anything, according to Bergson, it is nothing." (P. Marrati, "Le nouveau en train de se faire. Sur le bergsonisme de Deleuze," in Revue Internationale de Philosophie, n 3, 2007, p. 263 , transl. mine). 
of which actual things are crystallizations, it cannot be said to be conceived starting from what it conditions. ${ }^{23}$

There is a second argument why Bergson cannot be accused of deducing the pure past from the determinate representations of that past. When we consider that the determinate allows for juxtaposition, we see that the accusation would imply that Bergson conceives time spatially, i.e., as the succession of actual presents, as the container wherein determinate, homogeneous elements are juxtaposed. The following passage shows that Merleau-Ponty is thinking precisely along such lines:

Successives do not make a line: where would we align them? This not only means (Bergson) that the spatial symbolization of time transforms time, deforms it, substitutes the exterior for the interior, division for indivision, such that one would have to find anew [a] contact with "fusion" and "interpenetration'; [it also means that] this would still be series, but an immaterial series. And the critique holds for every series, be it spiritual or spatial..$^{24}$

Bergson's well-known critique of a spatial conception of time and the alternative he puts forward are not enough, according to Merleau-Ponty. $\mathrm{He}$ writes: "In order to arrive at authentic time, it is neither necessary nor sufficient to condemn the spatialization of time as does Bergson." 25 Bergson's critique is not necessary: this is so simply because a spatial conception of time

${ }^{23}$ The notion of crystallization in this sentence is not a direct reference to Deleuze's notion of the crystal image (Cinema 2. The Time-Image). It resonates, rather, with the notion of contraction that Deleuze uses to describe the relation between the Bergsonian couple, the virtual and actual: matter (actual) is duration (virtual) that has been "infinitely slackened and relaxed," such that "its moments are placed outside one another" and one moment can appear when another one has disappeared (B, p. 86 [p. 89]). It was in order to stress the non-resemblance between the virtual and the actual that I replaced "contraction" with "crystallization," a process that presupposes a continuity between its two poles, but is also characterized by a radical change of form. In Bergsonism, this change is described in terms of a dismantling of virtual coexistence. In the actual, the Whole is expressed in a specific way, according to a particular aspect or point of view, such that the different expressions are distinguished from one another (B, pp. 100-101 [pp. 104-105])

24 "Les successifs ne font pas une ligne: où les alignerions-nous? Ceci ne veut pas dire seulement (Bergson): la symbolisation spatiale du temps le transforme, le déforme, c'est l'extérieur substitué à l'intérieur, la division à l'indivision, de sorte qu'il faudrait retrouver [un] contact avec [la] 'fusion' et 'l'interpénétration': ce serait encore série, simplement immatérielle; la critique porte sur toute série, spirituelle aussi que spatiale." (M. Merleau-Ponty, Notes de cours 1959-1961, Paris: Gallimard, 1996, p. 199, transl. mine).

${ }^{25}$ Merleau-Ponty continues: "It is not necessary, since time is exclusive of space only if we consider space as objectified in advance, and ignore that primordial spatiality which we have tried to describe, and which is the abstract form of our presence in the world. It is not sufficient since, even when the systematic translation of time into spatial terms has been duly stigmatized, we may still fall very far short of an authentic intuition of time. This is what happened to Bergson." (PP, p. 415 footnote 1 [pp. 474-475]) 
is not necessarily problematic, provided, of course, that space be understood as depth, as a primordial bodily presence towards the world that is always in excess of itself. And his critique is not sufficient because it does not imply that one actually has an "authentic intuition of time"; a negative knowledge of time does not necessarily imply a positive knowledge of it.

Merleau-Ponty is essentially unfair in his polemic against Bergson. He blames Bergson for not considering other kinds of spatiality in order to think time. And yet, the spatiality Merleau-Ponty advances meets all the requirements Bergson mentions with respect to the conception of time. Space, in Merleau-Ponty as in Bergson, is not a homogeneous container wherein determinate, objective identities are juxtaposed; it is, instead, a quality in which everything is comprised of everything. This means that what is not actually perceivable (for example, the end of the street I am looking at through my window) is nevertheless equally present in an actual spatial perception (for instance, my perception of the street). Every spatial perception thus already carries within it what has previously been perceived and what is still to be perceived. All of this perfectly matches the continuity and the qualitative character of time that Bergson discusses.

\section{Bergson in The Visible and the Invisible}

Bergson occupies a central place in Merleau-Ponty's reflections on time in The Visible and the Invisible: the concept of "partial coincidence", crucial to Merleau-Ponty's argument, is one he borrows from Bergson.

According to Merleau-Ponty, it is impossible to recall the past as it was: our present cannot coincide with the being of the past; every memory bears the traces of our search for it. Were this not the case, we would be unable to distinguish the past from the present. This is not to say, however, that a memory is nothing but a trace, i.e., a construction without any inscription of the past. For that would mean, first, that there is in fact no past, only a present, and, hence, that there is no access to the past, but only to the present. Merleau-Ponty believes that we can only partially coincide with the past; this coincidence, he says elsewhere, has always already happened or is always about to happen-but never actually happens. As such, the past we appeal to is an impossible past, a past that has never been "present". ${ }^{26}$ It is "the past such as it was one day plus an inexplicable alteration, a strange distance-bound in

26 "Hence reflection does not itself grasp its full significance unless it refers to the unreflective fund of experience which it presupposes, upon which it draws, and which constitutes for it a kind of original past, a past which has never been a present." (PP, p. 242 [p. 280]) And: "It is a coincidence always past or always future, an experience that remembers an impossible past, anticipates an impossible future, [...]." (M. Merleau-Ponty, The Visible and the Invisible, English trans. by A. Lingis, Evanston: Northwestern University Press, 1968 [1964], pp. 122-123 [p. 164]) Henceforward abbreviated as VI. 
principle as well as in fact to a recalling that spans that distance but does not nullify it." ${ }^{27}$

Merleau-Ponty embraces this very Bergsonian idea (as does Deleuze, incidentall ${ }^{28}$ ), and yet he accuses Bergson of having failed to realize that the impossibility of a complete coincidence with the past is, paradoxically, the opening to the past. ${ }^{29}$ Merleau-Ponty's argument anticipates the analysis of sensation he will develop later, in The Visible and the Invisible: it is impossible to have, simultaneously, a sensation of the touching of one's hand and of the being touched of one's hand. One always switches positions, and this chiasm is what makes access to the world of the touched things, the "objective" world, possible. Similarly, the divergence (écart) that separates us from the past as it was is also our way of access to the past. This is not simply a matter of fact, but a matter of principle. ${ }^{30}$ The "partial coincidence" is not so much a regrettable side effect of our human condition but the condition of possibility and the condition of reality of memory. Bergson, Merleau-Ponty argues, underestimated the constitutive power of the divergence (écart), of the hollow character of being, of non-being ${ }^{31}$.

Can we agree with this criticism of Bergson? Is it true that Bergson does not attribute any constitutive power to the non-coincidence with the pure past? Is its different nature, its indeterminate, non-signifying character, really not a positive characteristic?

Deleuze argues that it is. For him, the non-representational nature of the virtual is a constitutive characteristic because it allows the endless stream of actualizations to continue. It is exactly because the virtual can never be exhausted by the sum of its actualizations or representations, regardless of their infinite number, that the drive to actualize or represent is maintained..$^{32}$ These actualizations are necessary because they shape the virtual-they prevent it from being an empty form. In Merleau-Pontyan terms: the past must be

${ }^{27}$ VI, p. 124 [pp. 165].

28 "The ground then appears as an immemorial Memory or pure past, a past which itself was never present." (G. Deleuze, Difference and Repetition, English trans. by P. Patton, London/ New York: Continuum, 2004, [1968], p. 343 [p. 351])

29 "Like the philosophies of reflection, what Bergson lacks is the double reference, the identity of the retiring into oneself with the leaving of oneself, of the lived through with the distance." (VI, p. 124 [p. 165])

30 "It is therefore necessary that the deflection (écart), without which the experience of the thing or of the past would fall to zero, be also an openness upon the thing itself, to the past itself, that it enter into their definition. " (VI, p. 124 [p. 165])

31 "In short: nothingness (or rather non-being) is hollow and not hole. The open, in the sense of a hole, that is Sartre, is Bergson, [...]." (VI, p. 196 [p. 249])

32 "It [the pure past] cannot be represented, but without it there is no representation possible." (C.V. Boundas, "Deleuze-Bergson: an Ontology of the Virtual," in P. Patton (ed.), Deleuze: a Critical Reader, Oxford/Cambridge: Blackwell, 1996, p. 93) 
anchored to the present, and this can only happen in the form of a past with which we only partially coincide.

In this context, it is remarkable that both Deleuze and Merleau-Ponty use the image of opposing mirrors to illustrate the non-coincidence of the condition. Merleau-Ponty writes that, just as it is impossible to trace the origin of the image when two mirrors are set opposite one another, so too it is impossible to identify the origin of our memories. ${ }^{33}$ In one sense, this origin is the pure past, but, as we cannot coincide with it and are always directed towards the concrete representations partially covering it, the latter, too, can be regarded as the origin. Deleuze turns to the figure of two opposing mirrors in the context of the crystal-image and of the discussion of the indiscernability of the actual and the virtual in that direct image of time. In a movie, the mirror image is virtual with regards to the actual person whose image is reflected in the mirror, but it is actual with regards to the person who is being driven outside the mirror image and thus being virtualized. ${ }^{34}$

To sum up: both Merleau-Ponty and Bergson (as he is presented and copied by Deleuze) believe that the pure past has to be understood as something we can never have access to with our representational instruments; it can only be present to or accessed by a kind of thinking that recognizes the indiscernability of the actual and the virtual, as Bergson and Deleuze contend, or by a form of thinking that acknowledges the transcendence in itself of the actual, as Merleau-Ponty claims. ${ }^{35}$ The latter thinking values these "holes" as the direct presence of the transcendental condition - the pure past. The resonances we touched upon in the course of this discussion - i.e. those regarding the simultaneity of past and present and those with respect to the idea of partial coincidence - indicate that Merleau-Ponty could have found an ally in Bergson instead of an "opponent." Bergson's notion of "partial coincidence" could in fact be read as endorsing Merleau-Ponty's notion of immanent transcendence. More generally, we can say that, had Merleau-Ponty focused on the Bergsonian concepts Deleuze uses, a different Bergson would have appeared, perhaps even a Bergson not in need of as much "correction" as Merleau-Ponty likes to present it. Indeed, Merleau-Ponty's alternative to Bergson is not as different from what we find in Bergson as Merleau-Ponty's presentation of it would have us think.

\section{The not-all-too-deep water}

Let us now return to the question we raised in response to Deleuze's reference, in The Movement-Image, to phenomenology in general and to MerleauPonty in particular. Is Deleuze's description of Merleau-Ponty's theory of time

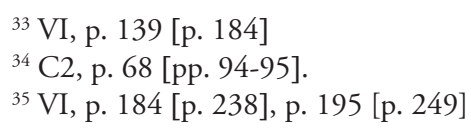


correct? Does Merleau-Ponty really see time as the neutral frame one must presuppose in order to think the transition of one existentially-fixed Gestalt to another? Is it the case that time in Merleau-Ponty has no ontological reality, no intrinsic relation to the things that move and to the way they move?

We should note from the outset that Merleau-Ponty's conception of time relies heavily upon some crucial Bergsonian insights. Just like Bergson, Merleau-Ponty pits against the explanation of the passing of time in terms of a succession of now-moments the simultaneity of present and past: "The definition of time [...] which might be formulated as "a succession of instances of now" has not even the disadvantage of treating past and future as present: it is inconsistent, since it destroys the very notion of "now', and that of succession." 36 And, again like Bergson, Merleau-Ponty believes that the present does not reach out towards a resembling past experience, but to the past in its entirety. Finally, Merleau-Ponty, like his predecessor, believes time to be the only eternity possible: the only thing that remains the same throughout all becoming and change is the fact of changing itself. ${ }^{37}$ Time is that which accounts for all differences by being itself nothing more than differentiation. ${ }^{38}$ Merleau-Ponty even uses Bergsonian metaphors, such as contraction and concentration, in order to explain the relation between time and its different actualizations. ${ }^{39}$

Together, these elements show that Merleau-Ponty cannot easily be assimilated to the group of philosophers who think time to be a neutral container.

But how to understand the crucial difference Fabrice Colonna identifies between Merleau-Ponty and Bergson? Colonna argues that Merleau-Ponty develops his notion of depth in response to the extrinsic relation between the virtual past and the actual present in Bergson—as Merleau-Ponty reads him. Depth perception indicates that the present itself always reaches out towards other dimensions. Present and past are not merely related to one another as layers, as Bergson's metaphor suggests. According to Merleau-Ponty,

${ }^{36}$ PP, p. 412 [pp. 471-472]. See also PP, p. 421 [p. 481].

${ }^{37}$ Merleau-Ponty compares the unity of time with the unity of a fountain jet: there is one jet of water although the water changes. (PP, p. 421, [p. 482]) In Notes de cours, Merleau-Ponty uses the Nietzschean notion of the eternal recurrence to describe the ceaseless creation of the new. (M. Merleau-Ponty, Notes de cours 1959-1961, Paris: Gallimard, 1996, p. 209). The notion of the eternal return also plays a crucial role in Deleuze's philosophy of difference (see for example, G. Deleuze, Difference and Repetition, English trans. by P. Patton, London/New York: Continuum, 2004, [1968], p. 153 [p. 164]).

38 "What is perfectly clear, is that this primordial temporality is not a juxtaposition of external events, since it is the power which holds them together while keeping them apart" (PP, p. $422[$ [p. 483]).

39 " $\mathrm{C}$ is the culmination of a long concentration which has brought it to maturity; as it was being built up, it made its approach known by progressively fewer Abschattungen, for it was approaching bodily. When it came into the present it brought with it its genesis, of which it was merely the ultimate expression (...). Time maintains what it has caused to be" (PP, p. 420 [p. 480]). 
the present contains the past: past and present are intrinsic to one another, and not bordering on one another. According to Colonna, Merleau-Ponty signals his break with Bergson when he replaces the "virtual" with "simultaneity" and "flesh," and "differentiation" with "bursting forth" (éclatement) and "dehiscence". ${ }^{40}$

We have tried to show that Merleau-Ponty's dismissal of the hidden, transcendent character of Bergson's pure past is not justified. More accurately put: when we read Bergson through Deleuze, we see that there is little reason to say that Bergson neglects the transcendent moment in the present itself, ${ }^{41}$ or that he appeals to a layer transcendent to the present. However, as we have approached Bergson mainly through readings of his work, and as his own texts are often quite ambiguous, we cannot regard our argument as a proof that Merleau-Ponty has misread Bergson. What the discussion does show, however, is that Merleau-Ponty's reworking of Bergson is not that different from Deleuze's. It is rather surprising to see that, in Cinema 1: The Time-Image, Deleuze refers to Merleau-Ponty's notion of depth in the course of his discussion of depth of field as a filmic means to present a direct image of time. Deleuze picks up the notion Merleau-Ponty introduces as he attempts to tackle Bergson's transcendent virtual, and incorporates it into his own theory, which is explicitly Bergsonian.

Moreover, Colonna's description of where Merleau-Ponty's notion of depth leads him brings Merleau-Ponty very close to Deleuze. Colonna suggests that Merleau-Ponty's big "discovery" is the insight that the combination of what Leibniz would regard as incompossible-present and non-present or past—results in movement. Consequentially, "flesh" or "simultaneity" only make sense as that which pushes difference forward, not by virtue of its own unity, but by virtue of its difference. Colonna concludes:

This image of the stabilized bursting forth of Being makes Merleau-Ponty's philosophy an ontology of Difference. Simultaneity is the ontological unity of difference $[\ldots]$. There is simultaneity, not in spite of difference, but because of difference. The difference is never different enough to cause a separation; its identity, however, is not posited at the outset as something apart, as something

${ }^{40}$ PP, p. 420 [p. 480]

${ }^{41}$ Deleuze himself would, of course, never call this the transcendent moment within the present; he would be kept from such language by his attempt to develop an immanent philosophy. Nevertheless, all the characteristics he attributes to the virtual - that it is non-representational, that it is differently determined than the actual, that it is non-chronological in character, etc.- - sketch an image of the virtual as something that is not-actual, and thus something that transcends it. This transcendence, however, differs from a classical transcendence in that the virtual is situated within the actual. It is in this sense legitimate for us to speak of an immanent transcendence. 
whose integrity would be threatened by difference. On the contrary, identity is itself constituted through the movement of difference. ${ }^{42}$

Hence the divergence in the way Merleau-Ponty and Deleuze refer to Bergson-the first, critically, the second, sympathetically-does not keep them from ending up on similar ground, namely on a quite Bergsonian interest in the constitutive character of difference. In their philosophies, MerleauPonty and Deleuze attempt to trace the origin of the highly differentiated character of the world without appealing to a unique, identical principle that is transcendent in relation to the world. Both end up with a kind of vitalism that cherishes creation and dynamism. I would like to suggest that Deleuze's conceptual tools have a more solid basis for working out this philosophy of difference than those mobilized by Merleau-Ponty;a proper argument for this contention is, however, beyond the scope of this paper. .

\author{
Judith Wambacq \\ Department of Art, Music \\ and Theatre Sciences \\ Ghent University \\ lokaal TV O1 \\ Blandijnberg 2 \\ 9000 Ghent, Belgium \\ Judith.Wambacq@UGent.be
}

42 “Cette image de l'éclatement stabilisé de l'Etre fait de la philosophie de Merleau-Ponty une ontologie de la Différence. La simultanéité est l'unité ontologique de la différence (...). Il y a simultanéité non pas malgré la différence mais par la différence. La différence ne diffère jamais suffisamment pour qu'il y ait séparation, mais l'identité quant à elle n'est pas posée d'emblée à part, en sorte que la différence la mettrait en cause, mais elle se constitue à même le mouvement de la différence." (F. Colonna, "Merleau-Ponty et la simultanéité," in Chiasmi International 4 (2002), Merleau-Ponty. Figures et fonds de la chair, p. 232, transl. mine). 